\title{
Policy brief: Adolescent girls and migration in the developing world
}

Population Council

Follow this and additional works at: https://knowledgecommons.popcouncil.org/departments_sbsr-pgy

Part of the Demography, Population, and Ecology Commons, Family, Life Course, and Society

Commons, Gender and Sexuality Commons, International Public Health Commons, Medicine and Health Commons, and the Migration Studies Commons

How does access to this work benefit you? Let us know!

\section{Recommended Citation}

"Policy brief: Adolescent girls and migration in the developing world." New York: Population Council, 2013. 
ADOLESCENT GIRLS

AND MIGRATION IN THE

DEVELOPING WORLD 


\section{(2) Population Council}

The Population Council confronts critical health and development issues-from stopping the spread of HIV to improving reproductive health and ensuring that young people lead full and productive lives. Through biomedical, social science, and public health research in 50 countries, we work with our partners to deliver solutions that lead to more effective policies, programs, and technologies that improve lives around the world. Established in 1952 and headquartered in New York, the Council is a nongovernmental, nonprofit organization governed by an international board of trustees.

Population Council

One Dag Hammarskjold Plaza

New York, NY 10017

www.popcouncil.org

Support for this project was generously provided by the Nike Foundation and United Nations Foundation. The views expressed are those of the authors and should not be attributed to the funders of the report.

For more information, contact the Population Council's Office of Strategic Communications; pubinfo@popcouncil.org | +1212-339-0509

(c) 2013 The Population Council, Inc.

Photo credits: (Page 5) Ollivier Girard; (page 6) Phil Borges. 


\section{INTRODUCTION}

Migration is transforming our world: by the end of this decade, most developing countries will have more people living in cities than in rural areas. Most migrants are in their early to mid-20s. Substantial numbers of adolescent girls are also on the move, but more information is needed about them and their journeys.

When a migrant girl is successful, she creates a ripple effect through generations: families and future children will be better off because of her ability to finish school, get a job, and stay healthy. When done right-with resources and safety nets in place-migration can be a source of new opportunities and benefits for girls. Despite the positive potential of migration for adolescent girls, migrant girls are largely ignored in policy and programs designed to reach migrants and adolescents.

Because of their age and gender, migrant girls are especially vulnerable to risks such as exploitative employment. Rural-to-urban moves may be particularly disorienting given the stark contrast in these environments, the values and behaviors of peers, and the pace of city life.

But cities are also areas with concentrated resources-schools, diverse job markets, health care-and new ways of thinking about gender. Girls who move to cities may be more able to make choices about their own lives given the greater autonomy they may have after migration. Many girls move because they are determined and motivated to improve their circumstances. If these girls arrive at their destination and settle in safely, their diligence and industriousness can enable them to capitalize on new opportunities and become productive, contributing members of their community-making lasting changes in their lives and the lives of their family members.

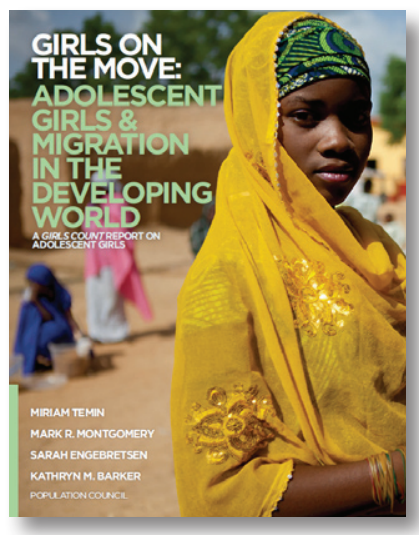

But more evidence is needed on how to maximize migration's benefits and minimize its risks for adolescent girls.

To respond to this need, the Population Council developed Girls on the Move: Adolescent Girls \& Migration in the Developing World, a new report in the Girls Count series. The report is the first of its kind to examine the social and economic drivers of internal migration for adolescent girls in developing countries, and the links between migration, risk, 
and opportunity. The authors explore a wide range of evidence on migrant girls, including findings on programming. They provide recommendations to make migration safer and increase its benefits. This policy brief provides a summary of key findings and recommendations from the report, available at: www.popcouncil.org/GirlsOnTheMove

\section{SCALE OF MIGRATION}

As shown in the figure below, substantial percentages of adolescent girls in the cities of developing countries are recent in-migrants. Although the international community has devoted much-needed attention to the dire situations of child refugees, street children, those in exploitative labor, and girls who are trafficked for sexual exploitation, the vast majority of the migrant girls who do not fall into these categories also need attention.

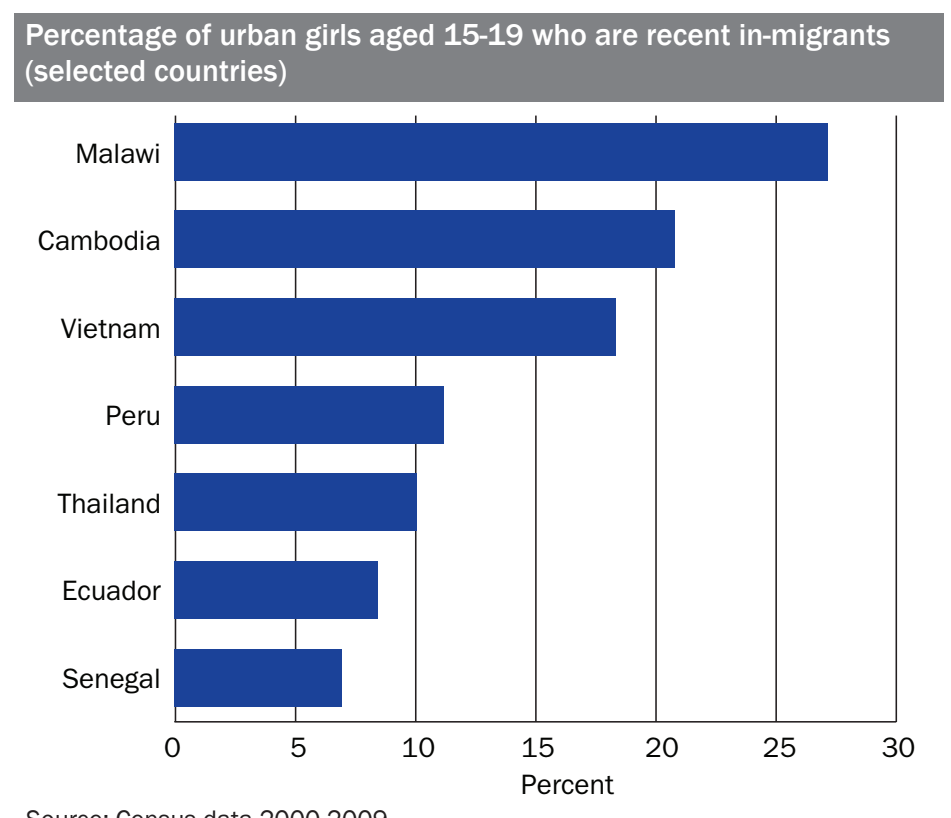

Source: Census data 2000-2009

\section{WHAT MOTIVATES GIRLS TO MIGRATE?}

Girls migrate for multiple reasons. New research for Girls on the Move shows that school and work opportunities (or both) are the primary reasons for adolescent girls' migration as shown in the figure below. A significant minority moves to escape hardship-such as neglect or abuse 
resulting from poverty or disruption of their family structure-and to escape child marriage (Erulkar et al. 2006).

Selected reasons for migration among Ethiopian females aged 10-19

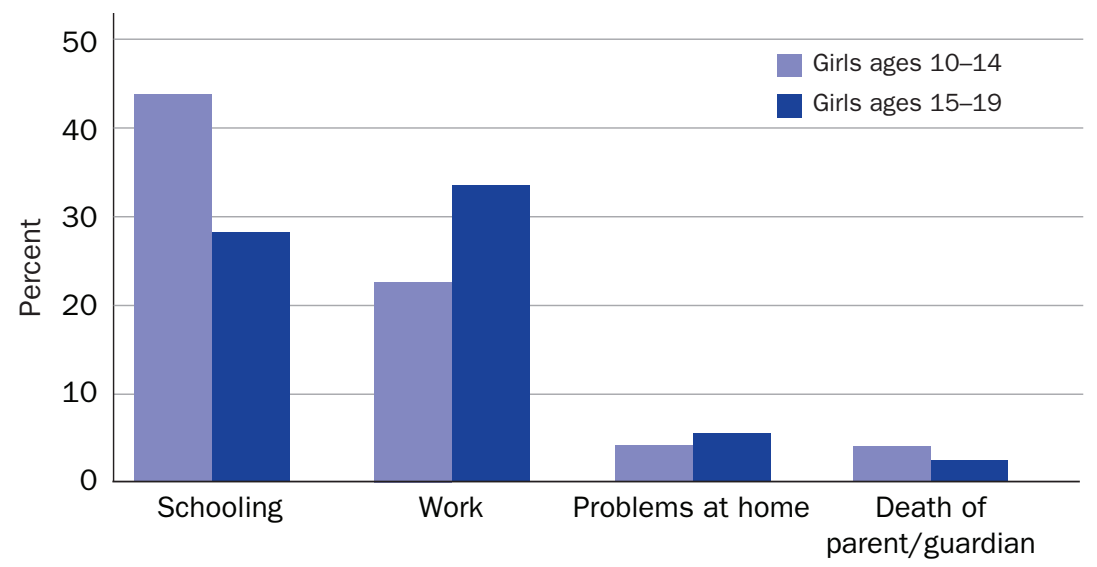

Source: Erulkar 2012

Limited schooling and job prospects in rural areas have a particularly strong influence on rural-to-urban migration. Secondary schools may be physically closer to urban homes, and education may be of higher quality. Rural employment may be limited, unpaid, and arduous, making the diversity of urban employment opportunities seem to be an attractive alternative. Girls also move to keep up with peers, who return to rural villages with new clothing and goods available only in cities. As a young migrant from Tanzania describes:

When [a girl who had migrated to the city] came back, she was very beautiful and she had money and everything, so I knew no matter how difficult life might be in the cities, still you can't compare with the village life...so I was waiting for an opportunity to come [to the city].

-SABINA, 17, TANZANIA (RWEHUMBIZA AND MABALA 2011: 9)

In addition to their personal betterment, girls also move to help provide for their family's needs, such as helping to pay for younger siblings' school fees. A girl from Vietnam explained:

I decided myself to leave and come here because I want to help my family because they are poor. 
The circumstances behind the decision to migrate vary, and the decisionmaking process preceding a girl's migration can be complex. Familial pressure and obligations interact with a girl's personal desire to move. Girls may also encounter roadblocks in their journeys, as illustrated in the figure below. Accurate information, material support, and social support from trusted individuals are essential for girls to reach their destination safely and fully integrate into their new communities.

Possible roadblocks to girls' safe and successful migration:

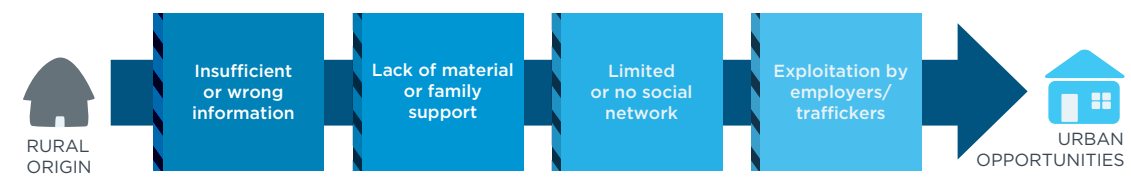

\section{BENEFITS OF MIGRATION}

When a girl is able to migrate safely with the appropriate protective assets, she is positioned to take advantage of resources, institutions, and opportunities unavailable at home.

\section{What is an asset?}

An asset is a store of value, something that girls can use to reduce vulnerabilities and expand opportunities (Austrian and Ghati 2010).

Protective assets for successful migration include:

\section{HUMAN}

- Skills and knowledge

- Good health

- Self-esteem

- Bargaining power

- Control over decisions

\section{PHYSICAL}

- Personal belongings

(mobile phone)

- Housing

- Transport

- Personal documentation

\section{SOCIAL}

- Trusted family, friends, mentors

- Social networks

- Group membership

- Access to public services and institutions

\section{FINANCIAL}

- Cash

- Savings 
Migrant girls in urban areas typically have higher educational levels than rural non-migrant girls. The gains from sustaining adolescent girls' education improve their economic potential, delay sexual initiation, marriage, and childbearing, and reduce rates of HIV infection. Educated mothers also bring benefits to their children through improved health, hygiene, and nutrition, and more time and resources for their children.

Many migrant girls who are not in formal education also benefit from living in urban areas. Migrant adolescent girls engaged in domestic work in West Africa stress the value of urban employment, which provides "on the job training" and a way to gain practical skills and knowledge that could not be attained through formal schooling.

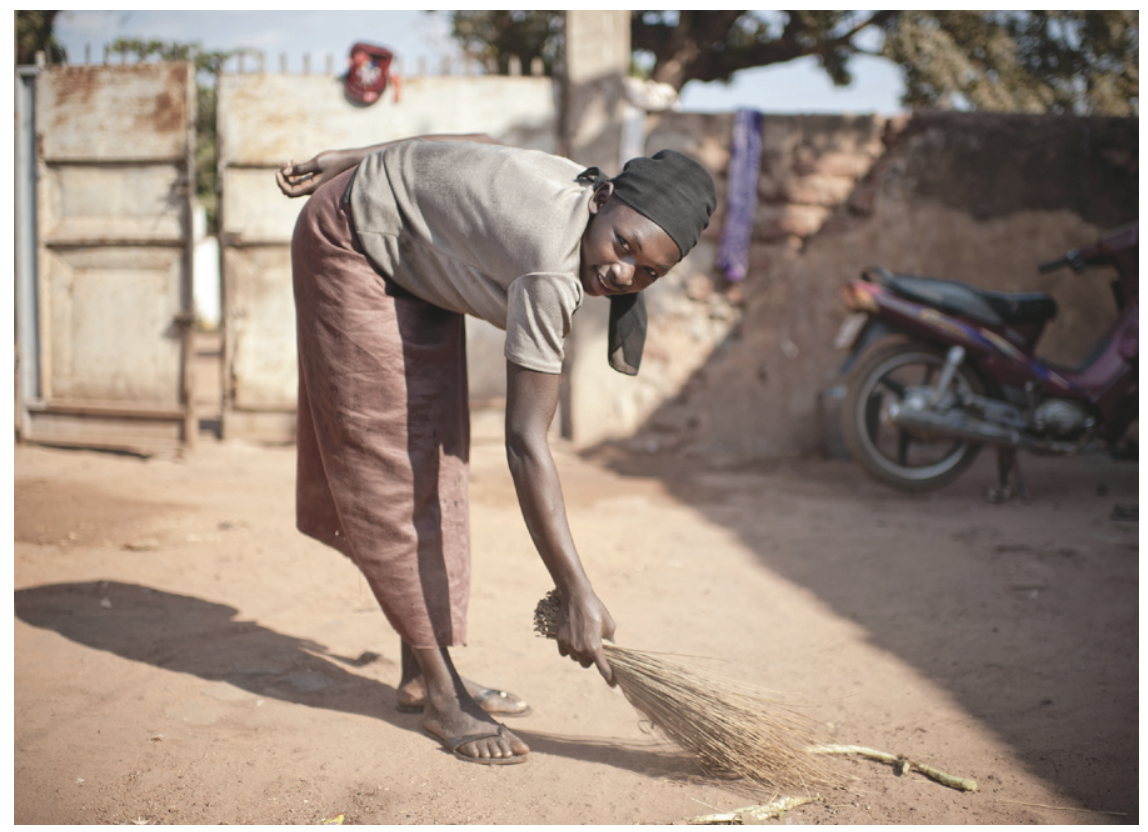

A participant from the Population Council's Filles Eveillées project in Burkina Faso for migrant girls in domestic service.

Migration can also empower adolescent girls economically. Working migrant girls can generate savings, which allow them to meet their basic needs and plan for the future. Evidence shows that some migrant girls also provide for their families with their earnings by caring for aging parents and paying for siblings' schooling. Remittances from migrant daughters can help raise the living standards of families in rural homes. 
When migrant girls successfully engage in school and work, they change the perception of girls' roles and position in society. Many parents report that a girl's status increases because of her ability to financially contribute to the family budget. This gives girls greater influence over family decisionmaking. In areas where many girls migrate, this may lead communities to re-think the importance of girls. This can affect marriage practices by reducing parents' and community elders' influence over the timing and choice of a husband.

Independent migration can loosen the grip of social control that dictates the terms of many girls' lives. Migrant girls may have more control over these terms than other girls, allowing them to postpone marriage. Finally, migration can lead to new social networks and different social norms. Exposure to new ways of thinking can play an important role in shaping the way a girl envisions her future and its possibilities.

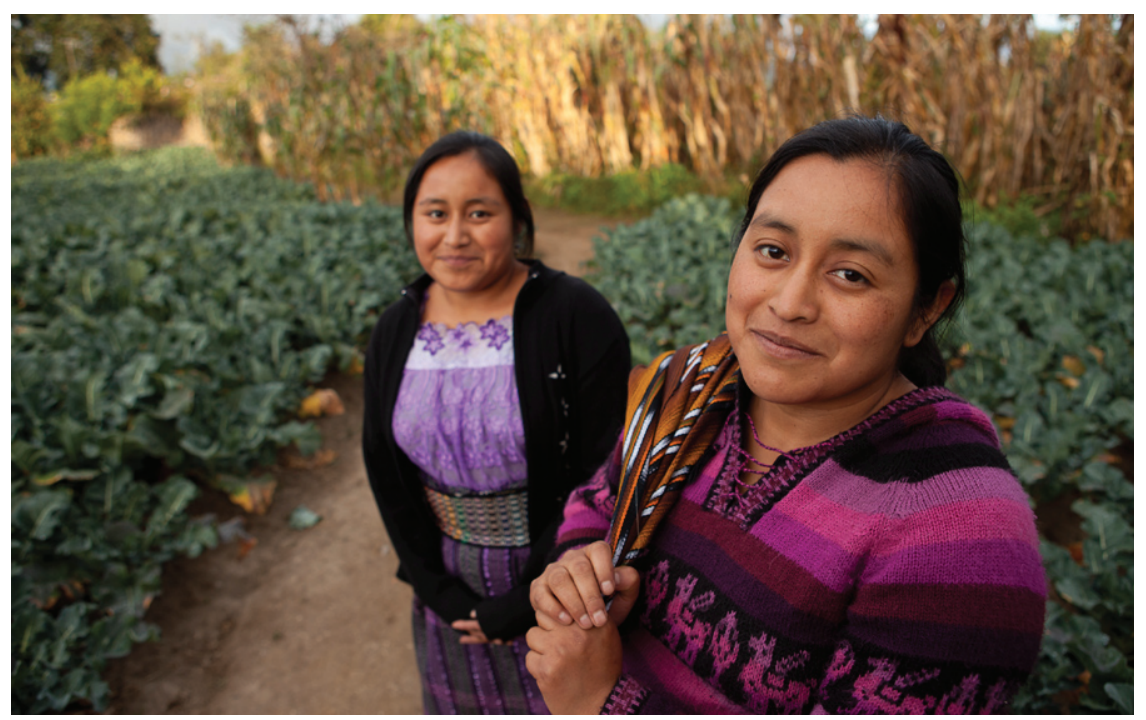

Participants in the Population Council's Abriendo Oportunidades program for young indigenous girls aged 8-18 in rural Guatemalan communities.

Qualitative research shows that even in difficult circumstances-enduring harsh work environments or living on the street-many migrant girls say they prefer their lives after migration to the lives they left behind. These girls see themselves as taking action to improve their circumstances and prospects, even if they must endure difficult situations to do so. 


\section{ACCELERATING ACTION FOR MIGRANT GIRLS}

Enabling migrant girls to secure their human rights, build their protective assets, and unlock their considerable potential requires a range of actions.

Given the diversity of migrant girls' experiences and needs, some migrant girls will be best reached through broad efforts to expand social service access; others will need targeted interventions such as "safe spaces" programs that provide a platform for the delivery of education and services. Many successful approaches rely on building girls' informal assets, including friendship networks and life skills, combined with interventions that link girls to formal assets and institutions such as identity papers, savings programs, and schools. In all program and policy design, it is essential to include input from migrant girls themselves.

\section{Promising approaches for migrant girls at each stage of their journey}

\section{PRE-MIGRATION}

- Accessible and relevant education (formal and non-formal)

- Life skills

- Vocational training

- Preparation for urban employment, savings, and risk management

- Portable assets such as birth certificates, identity cards, and mobile savings accounts
IN TRANSIT AND

\section{ON ARRIVAL}

- Trustworthy travel companion

- Adequate travel funds

- Information in transit hubs

- Access to mobile phones

- Safe accommodation

- Access to migrant or community groups

\section{SETTLING IN}

- Accessible and relevant education (formal and non-formal)

- High-quality, accessible health services

- Structured and regular access to same-sex peers

- Technology to stay in touch with family and friends

- Safe employment opportunities

- Access to savings programs

On the basis of the Council's research, the authors developed the Girls on the Move action agenda, which includes eight ways to maximize migrant girls' opportunities by protecting and supporting them. The action agenda is summarized on the last page of this brief, providing a road map for policymakers and program planners for increasing the visibility of migrant girls, reducing their vulnerability, and realizing their full potential. 


\section{IN SUM}

Adolescent girls are on the move in developing countries. They move to cities in the pursuit of better lives for themselves and their families. For the vast majority, migration can increase prosperity, opportunity, and provide girls with the autonomy to make decisions about their lives. For some girls, migration can lead to danger. Preventing the worst outcomes and helping migrant girls succeed is essential to unlock the benefits of migration. When migrant girls can take advantage of these benefits, they can be a powerful force for change in the developing world-improving lives and reducing poverty in their communities and nations.

\section{WORKS CITED}

Austrian, Karen and Dennitah Ghati. 2010. "Girl-centered program design: A toolkit to develop, strengthen and expand adolescent girls programs." Nairobi and New York: Population Council.

Erulkar, Annabel. 2012. "Preliminary analysis on Ethiopia Youth \& Gender survey (2009-2010)." Unpublished background paper for Girls on the Move: Commissioned Research Paper Series. New York: Population Council.

Erulkar, Annabel, Tekle-Ab Mekbib, Negussie Simie, and Tsehai Gulema. 2006. "Migration and vulnerability among adolescents in slum areas of Addis Ababa, Ethiopia." Journal of Youth Studies 9(3): 361-374.

Rushing, Rosanne. 2006. "Migration and sexual exploitation in Vietnam." Asian and Pacific Migration Journal 15(4): 471-494.

Rwehumbiza, Annagrace and Richard Mabala. 2011. "Through spike and spine, with family in the heart and dreams to accomplish: Stories of migrating adolescent girls in Tanzania." Unpublished background paper for Girls on the Move: Commissioned Research Paper Series. New York: Population Council. 


\section{RESOURCES}

\section{Population Council}

<www.popcouncil.org>

The Population Council has the largest body of research evaluating programs to improve the lives of adolescent girls. Through biomedical, social science, and public health research in 50 countries, we work with our partners to deliver solutions that lead to more effective policies, programs, and technologies that improve lives around the world.

\section{Coalition for Adolescent Girls <coalitionforadolescentgirls.org>}

The coalition hosts a website showcasing the Girls Count series. This series of reports uncovers adolescent girl-specific data and insights to drive meaningful action among policymakers, donors, the private sector, and development professionals.
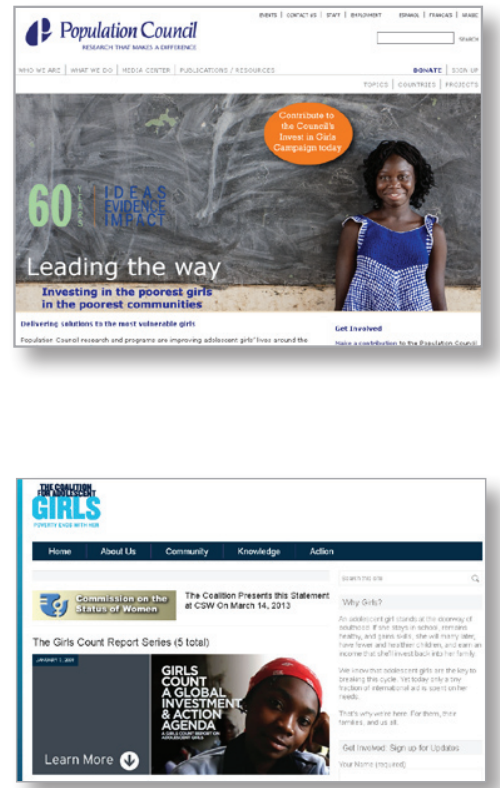


\section{TAKE ACTION FOR MIGRANT GIRLS}

PREPARE AND EQUIP GIRLS BEFORE THEY MIGRATE

Equip them with knowledge of their rights, life skills, IDs, and other portable assets.
TEST INNOVATIVE WAYS TO PREPARE MIGRANT GIRLS FOR SUCCESS Investigate ways to develop girls' assets before things go wrong.

\section{ENSURE A SMOOTH} LANDING: A SAFE

PLACE TO STAY AND SOCIAL CONNECTIONS

Reduce the risk of trafficking and exploitation by connecting girls with safe places to stay and trusted individuals.

CREATE TIME AND SPACE FOR MIGRANT GIRLS TO MEET FRIENDS AND MENTORS

Reduce isolation and vulnerability by building support networks.

\section{MAKE SERVICES} "MIGRANT GIRL FRIENDLY"

Ensure health and education services are sensitive to age, sex, and migration status.
FOCUS ON THE MOST

ISOLATED AND VULNERABLE

Design girl-only approaches to reach domestic workers, child brides, and sexually exploited girls.

FILL CRITICAL EVIDENCE GAPS

Illuminate internal migration rates using quantitative data. Develop qualitative and longitudinal studies to shed light on migrant girls' experiences.

INCREASE MIGRANT GIRLS' VISIBILITY THROUGH

\section{POLICY AND ADVOCACY}

Maximize the benefits of migration by increasing adolescent girls' visibility in policy and advocacy. 